\title{
Correction to: Breastfeeding knowledge of mothers in protracted crises: the Gaza Strip example
}

Alessandro lellamo ${ }^{1 *}$, Emily Monaghan ${ }^{1}$, Samar A. L. Moghany ${ }^{2}$, Jonathan Latham ${ }^{1}$ and Nihal Nassereddin ${ }^{3}$

Correction to: BMC Public Health 21, 742 (2021)

https://doi.org/10.1186/s12889-021-10748-2

It was highlighted that in the original article [1] the given name and family name of the first author, Alessandro Iellamo, were interchanged. The original article has been updated.

\section{Author details}

${ }^{1}$ Save the Children, London, UK. ${ }^{2}$ Save the Children International, Occupied

Palestine Territory, Gaza, Palestine. ${ }^{3}$ World Food Programme Palestine,

Jesuralem, Israel.

Published online: 12 May 2021

\section{Reference}

1. lellamo A, et al. Breastfeeding knowledge of mothers in protracted crises:

the Gaza Strip example. BMC Public Health. 2021;21:742. https://doi.org/1 0.1186/s12889-021-10748-2.

The original article can be found online at https://doi.org/10.1186/s12889 021-10748-2.

* Correspondence: a.iellamo@savethechildren.org.uk

'Save the Children, London, UK

Full list of author information is available at the end of the article

(c) The Author(s). 2021 Open Access This article is licensed under a Creative Commons Attribution 4.0 International License, which permits use, sharing, adaptation, distribution and reproduction in any medium or format, as long as you give appropriate credit to the original author(s) and the source, provide a link to the Creative Commons licence, and indicate if changes were made. The images or other third party material in this article are included in the article's Creative Commons licence, unless indicated otherwise in a credit line to the material. If material is not included in the article's Creative Commons licence and your intended use is not permitted by statutory regulation or exceeds the permitted use, you will need to obtain permission directly from the copyright holder. To view a copy of this licence, visit http://creativecommons.org/licenses/by/4.0/ The Creative Commons Public Domain Dedication waiver (http://creativecommons.org/publicdomain/zero/1.0/) applies to the data made available in this article, unless otherwise stated in a credit line to the data. 